\title{
PENGUATAN PENDIDIKAN KARAKTER MELALUI PEMBELAJARAN SEJARAH DI ERA REVOLUSI INDUSTRI 4.0
}

\author{
Yeni Asmara
}

\begin{abstract}
Abstrak
Pendidikan karakter dimaknai sebagai pendidikan yang mengembangkan karakter bangsa pada diri peserta didik dalam hal ini mahasiswa sehingga mereka memiliki nilai dan karakter dalam dirinya serta mampu mengimplementasikan nilai-nilai tersebut dalam kehidupan sehari-hari baik sebagai anggota masyarakat maupun warganegara yang religius, nasionalis, produktif dan kreatif. Karakter adalah bentuk watak, tabiat, akhlak yang melekat pada pribadi seseorang yang terbentuk dari hasil internalisasi yang digunakan sebagai landasan untuk berpikir dan berperilaku sehingga menimbulkan suatu ciri khas pada individu tersebut. Karakter individu akan berkembang dengan baik, apabila memperoleh penguatan yang tepat, yaitu berupa pendidikan.Era revolusi industri 4.0 merupakan tantangan berat bagi guru Indonesia. Mengutip dari Jack Ma dalam pertemuan tahunan World Economic Forum 2018, pendidikan adalah tantangan besar abad ini. Jika tidak mengubah cara mendidik dan belajar-mengajar, 30 tahun mendatang kita akan mengalami kesulitan besar. Pendidikan dan pembelajaran yang sarat dengan muatan pengetahuan mengesampingkan muatan sikap dan keterampilan sebagaimana saat ini terimplementasi, akan menghasilkan peserta didik yang tidak mampu berkompetisi dengan mesin. Dominasi pengetahuan dalam pendidikan dan pembelajaran harus diubah agar kelak anak-anak muda Indonesia mampu mengungguli kecerdasan mesin sekaligus mampu bersikap bijak dalam menggunakan mesin untuk kemaslahatan
\end{abstract}

Kata Kunci: Pendidikan karakter, Pembelajaran sejarah, Revolusi Industri 4.0

\section{Pendahuluan}

Pendidikan karakter dimaknai sebagai pendidikan yang mengembangkan karakter bangsa pada diri peserta didik dalam hal ini mahasiswa sehingga mereka memiliki nilai dan karakter dalam dirinya serta mampu mengimplementasikan nilai-nilai tersebut dalam kehidupan seharihari baik sebagai anggota masyarakat maupun warganegara yang religius, nasionalis, produktif dan kreatif. Karakter adalah bentuk watak, tabiat, akhlak yang melekat pada pribadi seseorang yang terbentuk dari hasil internalisasi yang digunakan sebagai landasan untuk berpikir dan berperilaku sehingga menimbulkan suatu ciri khas pada individu tersebut. Karakter individu akan berkembang dengan baik, apabila memperoleh penguatan yang tepat, yaitu berupa pendidikan.

Undang-Undang Republik Indonesia Nomor 20 Tahun 2003 tentang Sistem Pendidikan Nasional (Sisdiknas) telah merumuskan fungsi dan tujuan pendidikan nasional. Pasal 3 UU 
tersebut menyatakan, "Pendidikan nasional berfungsi mengembangkan kemampuan dan membentuk watak serta peradaban bangsa yang bermartabat dalam rangka mencerdaskan kehidupan bangsa, bertujuan untuk berkembangnya potensi peserta didik agar menjadi manusia yang beriman dan bertaqwa kepada Tuhan YME, berakhlak mulia, sehat, berilmu, cakap, mandiri, dan menjadi warga negara yang demokratis serta bertanggung jawab." Pasal tersebut merupakan dasar bagi pengembangan pendidikan karakter untuk pembentukan karakter manusia khususnya generasi muda. Pembinaan karakter manusia selaku generasi muda dapat ditempuh dengan berbagai upaya, termasuk melalui pendidikan yang dilakukan secara terprogram, bertahap, dan berkesinambungan (Hasan, 2010:6).

Proses dan hasil upaya pendidikan karakter dampaknya tidak akan terlihat dalam waktu yang segera, akan tetapi melalui proses yang panjang. Dengan adanya upaya tersebut setidaknya dosen sebagai pendidik telah membekali mahasiswa yang merupakan generasi muda bangsa diharapkan dapat memiliki daya tahan dan tangkal yang kuat dalam menghadapi berbagai permasalahan dan tantangan yang akan dihadapi pada saat ini maupun kedepan, termasuk tantangan dalam menghadapi kemajuan IPTEKS yang serba digital atau yang lebih dikenal dengan era revolusi industri 4.0 atau revolusi industri dunia ke-empat dimana teknologi telah menjadi basis dalam kehidupan manusia. Segala hal menjadi tanpa batas dan tidak terbatas akibat perkembangan internet dan teknologi digital. Era ini telah mempengaruhi banyak aspek kehidupan baik di bidang ekonomi, politik, kebudayaan, seni, dan bahkan sampai ke dunia pendidikan. Untuk menghadapi pengaruh atau dampak dari perubahan tersebut diperlukan suatu upaya yang dapat dilakukan terutama pada aspek pendidikan seperti salah satunya adalah melakukan penguatan pendidikan karakter. Seperti yang dijelaskan oleh Yahya (2018:4) bahwa strategi untuk menghadapi tantangan revolusi industri 4.0 salah satunya dengan melakukan revitalisasi sistem pembelajaran yakni mengintegrasikan pendidikan karakter ke dalam kurikulum. Dari pendapat di atas artinya penguatan pendidikan karakter dapat diintegrasikan melalui proses pembelajaran sejarah yang diselengarakan di setiap satuan pendidikan terutama Perguruan Tinggi. Pentingnya penguatan pendidikan karakter tersebut terutama mengadapi era revolusi industry 4.0 sebagai upaya mempertahankan nilai-nilai budaya bangsa sehingga di era milenial tersebut mahasiswa sebagai generasi bangsa Indonesia tidak kehilangan identitas bangsanya yang dikenal dengan bangsa yang menjunjung tinggi moralitas dan etika. Seperti yang 
telah dijelaskan sebelumnya bahwa di era revolusi 4.0 ilmu pengetahuan dan teknologi dapat berkembang sangat pesat tetapi tidak menutup kemungkinan sebagian manusia akan kehilangan jati diri mereka, kehilangan identitas diri apabila penguatan pendidikan karakter tidak diberikan, maka dari itu perlu dilakukan pengintegrasian pendidikan karakter ke dalam kurikulum seperti pelajaran sejarah.

Pengetahuan sejarah sangat fundamental dalam pembentukan identitas nasional juga sumber inpirasi yang sarat makna dalam pengembangan kesadaran sejarah para generasi muda . Soedjatmoko (dalam Wiyanarti,2012:2) mengatakan bahwa kesadaran sejarah merupakan orentasi intelektual dan sikap jiwa yang perlu untuk memahami secara tepat faham kepribadian nasional. Lebih lanjut dikatakan bahwa kesadaran sejarah akan mampu membimbing manusia kepada pengertian mengenai diri sendiri sebagai bangsa. Memahami betapa pentingnya kesadaran sejarah, maka pengembangan pendidikan sejarah merupakan tuntutan untuk melahirkan generasi bijaksana yang mampu menyelesaikan permasalahan bangsa dengan bijaksana. Oleh karena itu perlunya penguatan pendidikan karakter melalui pembelajaran sejarah untuk mengahadapi dampak dan permasalahan yang akan dihadapi di era revolusi industri 4.0 dengan tujuan untuk mempertahankan identitas dan integritas bangsa Indonesia.

\section{Pembahasan}

\section{Hakikat Pendidikan Karakter}

Karakter adalah bentuk watak, tabiat, akhlak yang melekat pada pribadi seseorang yang terbentuk dari hasil internalisasi yang digunakan sebagai landasan untuk berpikir dan berperilaku sehingga menimbulkan suatu ciri khas pada individu tersebut (Titin, 2008:682). Karakter individu akan berkembang dengan baik, apabila memperoleh penguatan yang tepat, yaitu berupa pendidikan. Pendidikan diharapkan mampu melahirkan masyarakat terdidik berakhlak mulia dan mampu meningkatkan kesadaran masyarakat untuk hidup secara harmonis, toleran dalam kemajemukan, berwawasan kebangsaan yang demokrasi serta berwawasan global seperti yang dijelaskan pada Pasal 3 Undang-Undang Nomor 20 Tahun 2003 tentang Sistem Pendidikan Nasional menyebutkan bahwa Pendidikan Nasional berfungsi mengembangkan kemampuan dan membentuk watak serta peradaban bangsa yang bermartabat dalam rangka mencerdaskan kehidupan bangsa, bertujuan untuk perkembangan 
potensi peserta didik agar menjadi manusia yang beriman dan bertakwa kepada Tuhan yang Maha Esa, berakhlak mulia, sehat, berilmu, cakap, kreatif, mandiri, dan menjadi warga negara yang demokratis serta bertanggung jawab. Untuk mencapai tujuan pendidikan nasional tersebut diperlukannya suatu upaya pendidikan karakter yang bertujuan dalam penanaman nilai dalam diri siswa dan pembaruan tata kehidupan bersama yang lebih menghargai kebebasan individu.

Pendidikan karakter menurut Thomas (dalam Sjarkawi, 2006: 45) merupakan pendidikan yang secara sengaja merancang penanaman dan pengembangan serta mengubah cara berpikir dan bertindak dalam situasi moral agar dapat diterima dalam lingkungan masyarakat. Pendidikan karakter membimbing individu untuk dapat menyelesaikan konflik dan untuk dapat bermasyarakat dengan moral yang baik. Menurut Gholar (dalam Zuchdi, 2011: 165) peserta didik perlu berusaha memecahkan masalah yang dihadapi sesuai dengan nilai-nilai keseharian, untuk itu peserta didik perlu memahami kepribadian diri sendiri dan lingkungan peserta didik.

Berdasarkan pemikiran beberapa ahli di atas mengenai definisi pendidikan karakter, maka dapat ditarik kesimpulan bahwa pendidikan karakter berusaha untuk menanamkan dan mengembangkan nilai-nilai karakter pada individu manusia dengan tujuan agar individu dalam hal ini peserta didik dapat memiliki tingkah laku yang sesuai dengan norma sehingga dapat diterima dalam lingkungan masyarakat. Disamping itu juga pendidikan karakter diharapkan dapat memberikan penguatan dan pengembangan mental agar peserta didik mampu menyelesaikan masalah yang dihadapi serta mempertanggungjawabkan masalah tersebut.

\section{Pembelajaran Sejarah}

Pendidikan sejarah di era global dewasa ini menghadapi tantangan dan dituntut kontribusinya untuk lebih menumbuhkan kesadaran sejarah, baik pada posisinya sebagai anggota masyarakat maupun warga negara, serta mempertebal semangat kebangsaan dan rasa cinta tanah air tanpa mengabaikan rasa kebersamaan dalam kehidupan antar bangsa di dunia. Pendidikan sejarah dapat meningkatkan kesadaran sejarah guna membangun kepribadian dan sikap mental peserta didik, serta membangkitkan kesadaran akan suatu 
dimensi yang paling mendasar dari keberadaan manusia, yakni kontinuitas. Melalui pendidikan sejarah peserta didik diajak menelaah keterkaitan kehidupan yang di alami diri, masyarakat dan bangsanya, sehingga mereka tumbuh menjadi generasi muda yang memiliki kesadaran sejarah, mendapatkan inspirasi ataupun hikmah dari kisah - kisah pahlawan , maupun tragedi nasional, yang pada akhirnya memdorong terbentuknya pola berfikir ke arah berfikir secara rasional - kritis -empiris, dan yang tidak kalah pentingnya ialah pembelajaran sejarah yang mengembangkan sikap mau menghargai nilai - nilai kemanusiaan.

Tujuan pendidikan sejarah menurut Bourdillon ( dalam Isjoni, 2007:112) idealnya adalah membantu peserta didik meraih kemampuan sebagai berikut : (1) memahami masa lalu dalam konteks masa kini, (2) membangkitkan minat terhadap masa lalu yang bermakna, (3) membantu memahami identitas diri, keluarga, masyarakat dan bangsanya , membantu memahami akar budaya dan inter relasinya dengan berbagai aspek kehidupan nyata , (5) memberikan pengetahuan dan pemahaman tentang negara dan budaya bangsa lain di berbagai belahan dunia, (6) melatih berinkuiri dan memecahkan masalah , (7) memperkenalkan pola berfikir ilmiah dari para ilmuwan sejarah sejarah, dan (8) mempersiapkan peserta didik untuk menempuh pendidikan yang lebih tinggi . Pokok pokok pemikiran tentang tujuan pendidikan sejarah tersebut di atas juga terkandung di dalam rumusan tujuan pendidikan sejarah di Indonesia. Hal senada dikemukakan juga dalam rumusan tujuan pendidikan sejarah di Indonesia, yang menyatakan bahwa pendidikan sejarah bertujuan untuk menyadarkan siswa akan adanya proses perubahan dan perkembangan masyarakat dalam dimensi waktu, dan untuk membangun perspektif serta kesadaran sejarah dalam menemukan, memahami, dan menjelaskan jati diri bangsa di masa lalu , masa kini , dan masa depan ditengah - tengah perubahan dunia.

Selama ini pendidikan sejarah di identikan sebagai pembelajaran yang membosankan di kelas . Baik strategi, metode maupun teknik pembelajaran lebih banyak bertumpu pada pendekatan berbasis guru yang monoton, dan meminimalkan partisipasi peserta didik . Guru di posisikan sebagai satu - satunya dan pokok sumber informasi , peserta didik tertinggal sebagai objek penderita manakala guru sebagai segala sumber dan pengelola informasi hanya mengajar dengan metode ceramah dan tanya jawab yang konvensional. Sehingga 220 | Seminar Nasional Sejarah ke 4 Jurusan Pendidikan Sejarah Universitas Negeri Padang 
pembelajaran sejarah disamping membosankan, juga hanya menjadi wahana pengembangan ketrampilan berfikir tingkat rendah dan tidak memberi peluang kemampuan berinkuiri maupun memecahkan masalah Memahami kenyataan umum pembelajaran sejarah di lapangan tersebut, yang menjadi penyebab utama adalah guru. Untuk itu para guru sejarah di lapangan di tantang untuk memiliki motivasi, keinginan, antusiasme dan kreatifitas mengembangkan dan meningkatkan kompetensi mengajar melalui pengayaan dan penguasaan berbagai model dan strategi pembelajaran sejarah, serta kemampuan mengaitkan konsep sejarah dengan kehidupan sehari-hari siswa sehingga pembelajaran sejarah dapat memberikan.

Belajar sejarah sejatinya bukan hanya belajar fakta-fakta untuk dihafal, melainkan bagaimana kemampuan dosen atau guru sejarah dalam menjelaskan materi dapat mengambil makna dari kejadian masa lalu, namun disayangkan secara umumnya lazimnya pembelajaran sejarah yang dilakukan di ruangan kelas hanyalah penyampaian peristiwa masa lalu kepada siswa dengan mengikuti garis-garis besar pedoman pembelajaran atau silabus dalam mata pelajaran sejarah Akibat dari situasi tersebut menyebabkan dosen ataupun guru sejarah kurang berkreasi dan berinovasi dalam menyampaikan pelajaran sejarah di sekolah (Mulyo, 2018:5). Di era Revolusi Industri 4.0 yang serba digital saat ini, seharusnya paradima pengajaran sejarah yang konvensional tersebut sudah semestinya ditinggalkan. Sudah saatnya pendidik sejarah mulai berinovasi dengan mengajar secara menarik, tentunya dengan mengintegrasikan pendidikan karakter dalam penyampaian materi sejarah sehingga mampu memberikan kesan yang mendalam bagi mahasiswa atau siswa yang mempelajarinya. Adapun nilai karakter yang dapat diintegrasikan melalui pembelajaran sejarah seperti nilai nasionalisme, patriotisme, bertanggung jawab, toleransi, dan sebagainya. Melalui penguatan pendidikan karakter di era revolusi industri 4.0 dengan pembelajaran sejarah diharapkan akan menjaga dan mampu mempertahankan identitas nasional bangsa Indonesia yang beradasarkan pada Pancasila . Karena bukan tidak mungkin di era revolusi industry 4.0 besarnya pengaruh budaya asing yang masuk ke Indonesia melalui kecanggihan teknologi dapat memberikan dampak negative bagi bangsa Indonesia apabila tidak diberikan upaya preventif seperti adanya penguatan pendidikan karakter yang 
dapat dilakukan dengan cara mengintegrasikannya ke dalam proses pembelajaran seperti salah satunya pelajaran sejarah.

\section{Sejarah Revolusi Industri 4.0}

Sejarah revolusi industri dimulai dari industri 1.0, 2.0, 3.0, hingga industri 4.0. Fase industri merupakan real change dari perubahan yang ada. Industri 1.0 ditandai dengan mekanisasi produksi untuk menunjang efektifitas dan efisiensi aktivitas manusia, industri 2.0 dicirikan oleh produksi massal dan standarisasi mutu, industri 3.0 ditandai dengan penyesuaian massal dan fleksibilitas manufaktur berbasis otomasi dan robot. Industri 4.0 selanjutnya hadir menggantikan industri 3.0 yang ditandai dengan cyber fisik dan kolaborasi manufaktur (Hermann et al, 2015; Irianto, 2017:40). Istilah industri 4.0 berasal dari sebuah proyek yang diprakarsai oleh pemerintah Jerman untuk mempromosikan komputerisasi manufaktur.

Lee et al (dalam Yahya,2018:67) menjelaskan, industri 4.0 ditandai dengan peningkatan digitalisasi manufaktur yang didorong oleh empat faktor: 1) peningkatan volume data, kekuatan komputasi, dan konektivitas; 2) munculnya analisis, kemampuan, dan kecerdasan bisnis; 3) terjadinya bentuk interaksi baru antara manusia dengan mesin; dan 4) perbaikan instruksi transfer digital ke dunia fisik, seperti robotika dan 3D printing. Lifter dan Tschiener (dalam Irianto, 2017:56) menambahkan, prinsip dasar industri 4.0 adalah penggabungan mesin, alur kerja, dan sistem, dengan menerapkan jaringan cerdas di sepanjang rantai dan proses produksi untuk mengendalikan satu sama lain secara mandiri.

Industri 4.0 merupakan industri yang menggabungkan teknologi otomatisasi dengan teknologi cyber. Ini merupakan tren otomatisasi dan pertukaran data dalam teknologi manufaktur, termasuk sistem cyber-fisik, internet untuk segala atau Internet of Things (IoT), komputasi awan dan komputasi kognitif. Industri 4.0 menghasilkan "pabrik cerdas". Di dalam pabrik cerdas berstruktur moduler, sistem siber-fisik mengawasi proses fisik, menciptakan salinan dunia fisik secara virtual, dan membuat keputusan yang tidak terpusat. Lewat internet untuk segala (IoT), sistem siber-fisik berkomunikasi dan bekerja sama dengan satu sama lain dan manusia secara bersamaan. Lewat komputasi awan (cloud 
computing), layanan internal dan lintas organisasi disediakan dan dimanfaatkan oleh berbagai pihak di dalam rantai nilai.

Industrialisasi dunia dimulai pada akhir abad ke-18 dengan munculnya tenaga uap dan penemuan kekuatan alat tenun, secara radikal mengubah bagaimana barang-barang diproduksi, masa ini disebut sebagai revolusi industri 1.0. Seabad kemudian, listrik dan jalur perakitan memungkinkan produksi massal, atau disebut revolusi industri 2.0. Pada 1970-an, revolusi industri 3.0 dimulai ketika kemajuan dalam otomatisasi bertenaga komputer memungkinkan seseorang memprogram mesin dan jaringan. Saat ini, revolusi industri keempat (4.0) mengubah ekonomi, pekerjaan, dan bahkan masyarakat itu sendiri. Hakikat Industri 4.0, merupakan penggabungan teknologi fisik dan digital melalui analitik, kecerdasan buatan, teknologi kognitif, dan Internet of Things (IoT) untuk menciptakan perusahaan digital yang saling terkait dan mampu menghasilkan keputusan yang lebih tepat.

Perusahaan digital dapat berkomunikasi, menganalisis, dan menggunakan data untuk mendorong tindakan cerdas di dunia fisik. Singkatnya, revolusi ini menanamkan teknologi yang cerdas dan terhubung tidak hanya di dalam perusahaan, tetapi juga kehidupan seharihari kita. World Economic Forum (WEF) menyebut Revolusi Industri 4.0 adalah revolusi berbasis Cyber Physical Systemyang secara garis besar merupakan gabungan tiga domain yaitu digital, fisik, dan biologi. Ditandai dengan munculnya fungsi-fungsi kecerdasan buatan (artificial intelligence), mobile supercomputing, intelligent robot, self-driving cars, neurotechnological brain enhancements, erabig data yang membutuhkan kemampuan cybersecurity, era pengembangan biotechnology dan genetic editing (manipulasi gen).

Era revolusi industri 4.0 mengubah konsep pekerjaan, struktur pekerjaan, dan kompetensi yang dibutuhkan dunia pekerjaan. Sebuah survei perusahaan perekrutan internasional, Robert Walters, bertajuk Salary Survey 2018 menyebutkan, fokus pada transformasi bisnis ke platform digital telah memicu permintaan profesional sumber daya manusia (SDM) yang memiliki kompetensi yang jauh berbeda dari sebelumnya. Dosen Institut Teknologi Bandung (ITB), Richard Mengko, yang mengambil sumber dari A.T. 
Kearney, mengungkap sejarah revolusi industri sampai akhirnya menyentuh generasi keempat. Berikut ini empat tahap evolusi industri dari awal hingga saat ini:

a. Akhir abad ke-18

Revolusi industri yang pertama terjadi pada akhir abad ke-18. Ditandai dengan ditemukannya alat tenun mekanis pertama pada 1784. Saat itu, industri diperkenalkan dengan fasilitas produksi mekanis menggunakan tenaga air dan uap. Peralatan kerja yang awalnya bergantung pada tenaga manusia dan hewan akhirnya digantikan dengan mesin tersebut. Banyak orang menganggur tapi produksi diyakini berlipat ganda.

b. Awal abad ke-20

Revolusi industri 2.0 terjadi di awal abad ke-20. Kala itu ada pengenalan produksi massal berdasarkan pembagian kerja. Lini produksi pertama melibatkan rumah potong hewan di Cincinnati, Amerika Serikat, pada 1870.

c. Awal 1970

Pada awal tahun 1970 ditengarai sebagai perdana kemunculan revolusi industri 3.0. Dimulai dengan penggunaan elektronik dan teknologi informasi guna otomatisasi produksi. Debut revolusi industri generasi ketiga ditandai dengan kemunculan pengontrol logika terprogram pertama (PLC), yakni modem 084-969. Sistem otomatisasi berbasis komputer ini membuat mesin industri tidak lagi dikendalikan manusia. Dampaknya memang biaya produksi menjadi lebih murah.

\section{d. Awal 2018}

Saat ini memasuki tahun 2018 merupakan zaman revolusi industri 4.0 yang ditandai dengan sistem cyber-physical. Dunia industri mulai menyentuh dunia virtual, berbentuk konektivitas manusia, mesin dan data, semua sudah ada di mana-mana. Istilah ini dikenal dengan nama internet of things (IoT).

Hermann et al (2016) menambahkan, ada empat desain prinsip industri 4.0. Pertama, interkoneksi (sambungan) yaitu kemampuan mesin, perangkat, sensor, dan orang untuk terhubung dan berkomunikasi satu sama lain melalui Internet of Things (IoT) atau Internet of People (IoP). Prinsip ini membutuhkan kolaborasi, keamanan, dan standar. Kedua, transparansi informasi merupakan kemampuan sistem informasi untuk menciptakan salinan virtual dunia fisik 224 | Seminar Nasional Sejarah ke 4 Jurusan Pendidikan Sejarah Universitas Negeri Padang 
dengan memperkaya model digital dengan data sensor termasuk analisis data dan penyediaan informasi. Ketiga, bantuan teknis yang meliputi; (a) kemampuan sistem bantuan untuk mendukung manusia dengan menggabungkan dan mengevaluasi informasi secara sadar untuk membuat keputusan yang tepat dan memecahkan masalah mendesak dalam waktu singkat; (b) kemampuan sistem untuk mendukung manusia dengan melakukan berbagai tugas yang tidak menyenangkan, terlalu melelahkan, atau tidak aman; (c) meliputi bantuan visual dan fisik. Keempat, keputusan terdesentralisasi yang merupakan kemampuan sistem fisik maya untuk membuat keputusan sendiri dan menjalankan tugas seefektif mungkin. Secara sederhana, prinsip industri 4.0 menurut Hermann et al (2016) dapat digambarkan sebagai berikut.

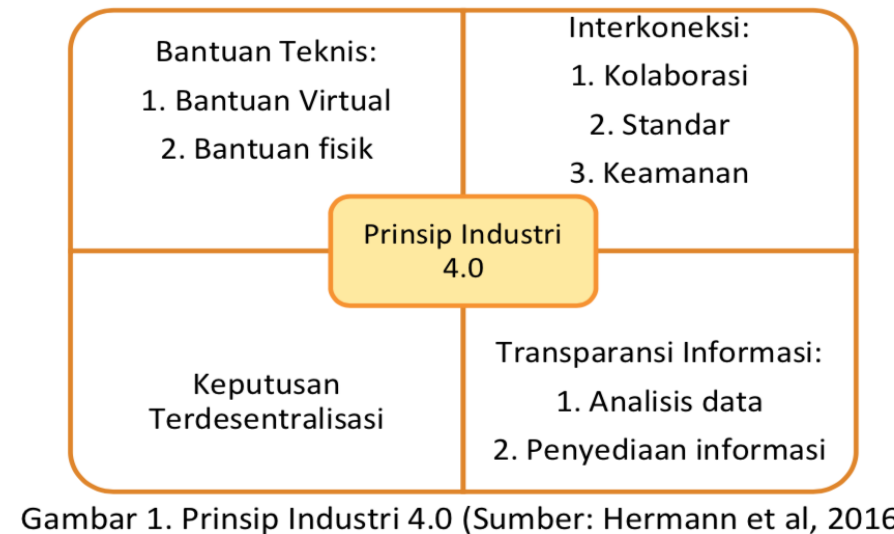

Industri 4.0 telah memperkenalkan teknologi produksi massal yang fleksibel (Kagermann et al, 2013). Mesin akan beroperasi secara independen atau berkoordinasi dengan manusia (Sung, 2017). Industri 4.0 merupakan sebuah pendekatan untuk mengontrol proses produksi dengan melakukan sinkronisasi waktu dengan melakukan penyatuan dan penyesuaian produksi (Kohler \& Weisz, 2016). Selanjutnya, Zesulka et al (dalam Sukartono,2018:56) menambahkan, industri 4.0 digunakan pada tiga faktor yang saling terkait yaitu; 1) digitalisasi dan interaksi ekonomi dengan teknik sederhana menuju jaringan ekonomi dengan teknik kompleks; 2) digitalisasi produk dan layanan; dan 3) model pasar baru.

Era revolusi industri 4.0 juga mengubah cara pandang tentang pendidikan. Perubahan yang dilakukan tidak hanya sekadar cara mengajar, tetapi jauh yang lebih esensial, yakni perubahan cara pandang terhadap konsep pendidikan itu sendiri. Pendidikan setidaknya harus mampu menyiapkan anak didiknya menghadapi tiga hal: a) menyiapkan anak untuk bisa bekerja 
yang pekerjaannya saat ini belum ada; b) menyiapkan anak untuk bisa menyelesaikan masalah yang masalahnya saat ini belum muncul, dan c) menyiapkan anak untuk bisa menggunakan teknologi yang sekarang teknologinya belum ditemukan. Sungguh sebuah pekerjaan rumah yang tidak mudah bagi dunia pendidikan. Untuk bisa menghadapi tantangan tersebut, syarat penting yang harus dipenuhi adalah bagaimana menyiapkan kualifikasi dan kompetensi guru yang berkualitas.

Era revolusi industri 4.0 merupakan tantangan berat bagi guru Indonesia. Mengutip dari Jack Ma dalam pertemuan tahunan World Economic Forum 2018, pendidikan adalah tantangan besar abad ini. Jika tidak mengubah cara mendidik dan belajar-mengajar, 30 tahun mendatang kita akan mengalami kesulitan besar. Pendidikan dan pembelajaran yang sarat dengan muatan pengetahuan mengesampingkan muatan sikap dan keterampilan sebagaimana saat ini terimplementasi, akan menghasilkan peserta didik yang tidak mampu berkompetisi dengan mesin. Dominasi pengetahuan dalam pendidikan dan pembelajaran harus diubah agar kelak anak-anak muda Indonesia mampu mengungguli kecerdasan mesin sekaligus mampu bersikap bijak dalam menggunakan mesin untuk kemaslahatan (Sukartono, 2018:78).

Era revolusi industri 4.0 akan berdampak pada peran pendidikan khususnya peran pendidiknya. Jika peran pendidik masih mempertahankan sebagai penyampai pengetahuan, maka mereka akan kehilangan peran seiring dengan perkembangan teknologi dan perubahan metode pembelajarannya. Kondisi tersebut harus diatasi dengan menambah kompetensi pendidik yang mendukung pengetahuan untuk eksplorasi dan penciptaan melalui pembelajaran mandiri.

Dalam kontek pembelajaran abad 21, pembelajaran yang menerapkan kreativitas, berpikir kritis, kerjasama, keterampilan komunikasi, kemasyarakatan dan keterampilan karakter, tetap harus dipertahankan bahwa sebagai lembaga pendidikan peserta didik tetap memerlukan kemampuan teknik. Pemanfaatan berbagai aktifitas pembelajaran yang mendukung i4.0 merupakan keharusan dengan model resource sharing dengan siapapun dan dimanapun, pembelajaran kelas dan lab dengan augmented dengan bahan virtual, bersifat interaktif, menantang, serta pembelajaran yang kaya isi bukan sekedar lengkap.

\section{DAFTAR PUSTAKA}

226 | Seminar Nasional Sejarah ke 4 Jurusan Pendidikan Sejarah Universitas Negeri Padang 
Hamid, Abdul .2018. Revolusi Industri 4.0, Peluang dan Tantangannya Bagi Pembelajaran Ilmu Sosial.https://www.unimed.ac.id/2018/10/11/revolusi-industri-4-0-peluang-dan tantangannya-bagi-pembelajaran-ilmu-sosial.

Herwina dan Iswan, 2018. Penguatan pendidikan karakter perspektif Islam Dalam era millenial ir. 4.0. Prosiding Seminar Nasional Pendidikan Era Revolusi "Membangun Sinergitas dalam Penguatan Pendidikan Karakter pada Era IR 4.0" Universitas Muhammadiyah Jakarta, Indonesia, 24 Maret 2018 ISSN : 2621-6477

Isjoni . 2007. Pembelajaran Sejarah . Bandung : Alfabeta

Sirnayatin, Ariska, Titin,2017. Membangun Karakter Bangsa Melalui pembelajaran sejarah. Jurnal SAP Vol. 1 No. 3 April 2017 p-ISSN: 2527-967X e-ISSN: 2549-2845 312.

Sjarkawi. 2006. Pembentukan Kepribadian Anak Peran Moral Intelektual, Emosional, dan Sosial Sebagai Wujud Integritas Membangun Jati Diri. Jakarta: Bumi Aksara.

Sunyoto, Mulyo.2018. Guru sejarah yang memikat siswa. Antara Online Kamis, 8 November 2018 13:03 WIB

Sukartono, 2018. Revolusi Industri 4.0 dan Dampaknya terhadap Pendidikan di Indonesia http://fkip.ums.ac.id/wp-content/uploads/sites/43/2018/12/Revolusi-Industri-4.0-danDampaknya-terhadap-Pendidikan-di-Indonesia

Wiyanarti,E.2012. Model pembelajaran kontekstual dalam pengembangan Pembelajaran Sejarah. Bandung: Universitas Pendidikan

Yahya, Muhammad, 2018. Era industri 4.0: Tantangan dan Peluang Perkembangan Pendidikan Kejuruan Indonesia. Disampaikan pada Sidang Terbuka Luar Biasa Senat Universitas Negeri Makassar Tanggal 14 Maret 2018.

Zuchdi, Darmiyati. 2011. Pendidikan Karakter Dalam Prespektif Teori dan Praktik. Yogyakarta: UNY Press. 